Original article

\title{
Prevalence of surgical site infection in patient with bile spillage during laparoscopic cholecystectomy
}

\section{Anuj Parajuli}

\section{Abstract}

Introduction: Iatrogenic gallbladder perforation with bile spillage (BS) during laparoscopic cholecystectomy (LC) occurs frequently but its impact to the patient can range from port site surgical site infection (SSI), bowel obstruction, intraperitoneal abscess to none. We aim to examine the prevalence of port site SSI in patients with bile spillage during laparoscopic cholecystectomy.

Methods: Aprospective descriptive cross-sectional study was undertaken which included consecutive patients who underwent LC over a period of six months and had intraoperative bile spillage. Patients were noted and evaluated for the presence of port site SSI. Patients were assessed clinically during hospitalization and on follow-up at five and even days post operatively. Bile spillage (BS) as a possible risk factor for port site surgical site infection (SSI) was analyzed.

Results: Out of 318 patients, there were $229(72 \%)$ female and $89(28 \%)$ male patients with a mean age of $46 \pm 11.7$ years. BS occurred in 66 $(20.8 \%)$ patients. Port site SSI was present in $14(4.4 \%)$ patients. SSI among patients with bile spillage was present in $8(12.1 \%)$ and among patients without BS was $6(2.3 \%)$.

Conclusion: The present study reveals that iatrogenic gallbladder perforation with BS has higher prevalence of port site SSI.

Keywords: Bile Spillage; Gall Bladder Perforation; Laparoscopic Cholecystectomy; Surgical Site Infection.

\section{Author affiliations:}

Department of surgery, Kathmandu Medical College Teaching Hospital, Sinamangal, Kathmandu, Nepal

\section{Correspondence:}

Dr. Anuj Parajuli,

Department of surgery, Kathmandu Medical College Teaching Hospital, Sinamangal, Kathmandu, Nepal.

Email: dranujparajuli@yahoo.com

ORCID: https://orcid.org/0000-0002-09650179

\section{Disclosures:}

Ethical Clearance: IRB of KMCTH

Conflict of interest: None

Financial aid: None

\section{Copyright information:}

Authors retain copyright and grant the journal righ of first publication with the work simultaneously licensed under Creative Commons Attribution License under CC-BY 4.0 that allows others to share the work with an acknowledgement of the works's authorship and initial publication of this journal.

\footnotetext{
How to cite this article:

Parajuli A. Prevalence of surgical site infection in patient with bile spillage during laparascopic cholecystectomy. J Soc Surg Nep. 2020 Dec;23(2):36-39.

DOI:

https://doi.org/10.3126/jssn.v23i2.35831
} 


\section{Introduction}

Laparoscopic surgery (LS) also termed as minimally invasive surgery has brought a paradigm shift in the approach to current surgical care. Introduced in the 20th century, it has become the surgical approach of choice for many procedures. ${ }^{1}$ Laparoscopic cholecystectomy (LC) is the gold standard technique to gall bladder surgery in modern era. ${ }^{2,3}$ LC edges over the conventional open method for early postoperative recovery, less pain, better cosmetic results, shorter hospital stay and early return to routine activities. ${ }^{4,5}$

Gallbladder perforation is one of the most common intraoperative complications encountered by surgeons, especially during the learning curve of laparoscopic cholecystectomy. Perforation may be secondary to traction of grasper forceps or from thermal injury during dissection. Although difficult to measure the accurate incidence worldwide, iatrogenic gall bladder perforation during laparoscopic cholecystectomy may occur in around $40 \%$ of the patients. ${ }^{6,7}$ Although infectious complications after $\mathrm{LC}$ are rare, some authors have reported that BS might be associated with port site surgical site infection (SSI) and can be troublesome complication to undermine the benefits of minimal invasive surgery. ${ }^{8-10}$ Although infrequently seen, it increases patient dissatisfaction and leads to frequent emergency visits, subsequent readmissions, additional procedures and increased overall cost. ${ }^{11,12}$ This could be a disappointing situation to the patient and the treating surgeon.

Therefore, we designed this study to examine the prevalence of port site SSI in patients with bile spillage during laparoscopic cholecystectomy surgery.

\section{Methods}

This is a descriptive cross-sectional study. Patients who underwent laparoscopic cholecystectomy for symptomatic biliary disease were included over a period of six months from June 1st 2019 to November 30th 2019 at Kathmandu Medical College Teaching Hospital.

Patients included were above 18 years of age, underwent laparoscopic or laparoscopic turned open procedure for biliary disease irrespective of pathophysiology and urgency which included biliary colic, symptomatic cholelithiasis, acute calculus cholecystitis, chronic calculus cholecystitis, empyema and biliary pancreatitis. Patients planned for open cholecystectomy or refusing to participate were excluded from the study. All patients were given single dose of intravenous antibiotics before surgery, however patients with comorbidities like diabetics mellitus, use of steroids, acute calculous cholecystitis, empyema of gallbladder etc. were continued with intravenous antibiotics during inhospital stay and oral antibiotics on discharge till the 7th postoperative day.

All surgeries were performed by consultants and final year surgical post graduate (PG) residents under supervision of respective unit consultants. Single dose of injection ceftriaxone $1 \mathrm{gm}$ was given 30 minutes before the surgical incision. Peritoneal lavage was done if BS was present, stone spillage was collected in the retrieval bag and removed along with the specimen from the umbilical port. Retrieval bag was routinely used for specimen retrieval. After completion of the procedure, study questionnaire was filled by the operating surgeon based on the intraoperative findings. Postoperative pain and intravenous fluid was managed as per the unit protocol. Patients were advised for dressing on alternate days and follow-up at five and seven days of surgery. Patients were clinically assessed and presence or absence of port site SSI was noted.

Surgical site infection was categorized as per the United States Center for Disease Control (CDC) guidelines. Port site SSI was classified as superficial (involving skin and subcutaneous tissues), deep (involving fascial and muscular layers) and organ/space (involving intrabdominal tissues and organs). ${ }^{13}$

Patient's age, gender, American Society of Anesthesiologist (ASA) grade, intraoperative findings (bile spillage, empyema, hydrops, gall stone spillage, stones retrieval, and peritoneal irrigation), SSI and interventions were noted.

Statistical analysis was done using Statistical Package for Social Sciences (SPSS, Inc., Chicago, Illinois) version 20. Patients who had intraoperative bile spillage were noted and looked for the presence of port site SSI. Data are presented in absolute number and percentage.

Ethical approval was taken from the Institutional Review Committee of Kathmandu Medical College Teaching Hospital and informed consent was taken from the patients.

\section{Results}

A total of 318 consecutive laparoscopic cholecystectomies were included. Table 1 describes the demographic and intraoperative characteristics of the patient. Majority of our patients $264(83 \%)$ had LC for symptomatic cholelithiasis. Out of the 318 laparoscopic cholecystectomy patients, there were $229(72 \%)$ female and $89(28 \%)$ male and their mean age was 46.79 (SD 11.7) years. Of note, $66(20.8 \%)$ patients had intraoperative bile spillage and in $24(7.5 \%)$ patients BS was accompanied by stone spillage. Port site SSI was observed in 14(4.4\%). Port site SSI was seen in $8(12.1 \%)$ out of the 66 patients with BS and $6(2.3 \%)$ out of the 252 patients without BS. All port site infection was superficial type and was treated with oral antibiotics and local wound care.

Conversion to open was necessary in two $(0.6 \%)$ patients for difficult dissection secondary to dense adhesions. In a situation of BS, operative time was prolonged because of extra time spent for intraperitoneal irrigation and retrieval of spilled stones. 
Table1. Demographic and intraoperative characteristics of patient population $(n=318)$

\begin{tabular}{|c|c|c|c|}
\hline Variables & \multicolumn{3}{|c|}{ Data } \\
\hline Age & \multicolumn{3}{|c|}{$46.7(\mathrm{SD} 11.7)$} \\
\hline Male/Female & \multicolumn{3}{|c|}{$89 / 229(28 / 72 \%)$} \\
\hline \multicolumn{4}{|l|}{ ASA, (n\%) } \\
\hline$<2$ ASA & \multicolumn{3}{|c|}{$307(96.5 \%)$} \\
\hline$>2 \mathrm{ASA}$ & \multicolumn{3}{|c|}{$11(3.5 \%)$} \\
\hline Pre-operative diagnosis & Number & $\begin{array}{l}\text { SSI } \\
\text { no. }\end{array}$ & $\begin{array}{c}\text { SSI \% } \\
(\mathrm{n}=318)\end{array}$ \\
\hline Biliary colic & 8 & 1 & $0.3 \%$ \\
\hline $\begin{array}{l}\text { Acute calculus } \\
\text { cholecystitis }\end{array}$ & 14 & 3 & $0.9 \%$ \\
\hline $\begin{array}{l}\text { Chronic calculus } \\
\text { cholecystitis }\end{array}$ & 8 & 1 & $0.3 \%$ \\
\hline Acute biliary pancreatitis & 10 & 0 & $0 \%$ \\
\hline Cholelithiasis & 264 & 9 & $2.8 \%$ \\
\hline GB polyp & 14 & 0 & $0 \%$ \\
\hline $\begin{array}{l}\text { Conversion to open, (n } \\
\% \text { ) }\end{array}$ & \multicolumn{3}{|c|}{$2(0.6 \%)$} \\
\hline Bile spillage, $(\mathrm{n} \%)$ & \multicolumn{3}{|c|}{$66(20.8 \%)$} \\
\hline Stone spillage, $(\mathrm{n} \%)$ & \multicolumn{3}{|c|}{$24(7.5 \%)$} \\
\hline Port site SSI & \multicolumn{3}{|c|}{$14(4.4 \%)$} \\
\hline $\begin{array}{l}30 \text { days re-admission, } \\
(\mathrm{n} \%)\end{array}$ & \multicolumn{3}{|c|}{$0(0 \%)$} \\
\hline
\end{tabular}

Table 2. Prevalence of port site SSI in patients with and without Bile spillage

\begin{tabular}{|lcc|}
\hline & SSI present $\mathbf{n}(\%)$ \\
\hline Bile spillage present & $(\mathrm{n}=66)$ & $8(12.1 \%)$ \\
\hline Bile spillage absent & $(\mathrm{n}=252)$ & $6(2.3 \%)$ \\
\hline
\end{tabular}

\section{Discussion}

Our study shows that, gall bladder (GB) perforation with BS during laparoscopic cholecystectomy occurs frequently and may increase the risk for port site SSI postoperatively. GB perforation during LC can occur due to acute inflammation causing friable tissue which is susceptible to tear on traction, dense adhesions secondary to acute or chronic inflammation, distended GB if not decompressed, and excessive traction during dissection from liver bed.

In a study by Sarli et $\mathrm{al}^{14}$ involving 1127 patients that underwent LC for cholelithiasis, BS was observed in 11.6\% and found no difference in postoperative complications between patients with and without BS. They concluded that postoperative complications could be minimized with adequate prophylactic antibiotics, retrieval of spilled stones, adequate peritoneal cavity irrigation and increasing surgical expertise.

In contrary to the previous study, Rice et a ${ }^{15}$ from Mayo Clinic concluded that intra peritoneal spillage of gall bladder content during LC significantly increased the risk of intra-abdominal abscess and port site SSI. They suggested, intra peritoneal irrigation and retrieval of all stones during the procedure may be beneficial to reduce the risk of complications related to the spillage. Another study by Peponis et $\mathrm{al}^{16}$, a prospective study in $1001 \mathrm{LC}$ patients, bile spillage was present in 591(59\%) and significantly associated with port site SSI $[7.1 \%(\mathrm{p}=0.001)]$. In our study GB perforation with BS among $66(20.8 \%)$ patients showed higher prevalence of port site SSI (Table 2). This could be secondary to intrinsic commensalism or external pathogens. Other factors related to port site SSI in BS patients could be inclusion of acute calculus cholecystitis, acute biliary pancreatitis, and chronic cholecystitis.

Acute or chronic inflammation of the gall bladder obscures the normal anatomic plane resulting in difficult manipulation and eventually gall bladder wall perforation. Other common factor is surgical residents performing the procedure. ${ }^{17}$ Our study had $66(20.8 \%)$ iatrogenic gall bladder perforation, this could be secondary to inclusion of acute and chronic gall bladder disease and increasing number of procedures performed by surgical residents under supervision. Once bile or stone spillage occurs during LC, every effort should be made to minimize the spillage by suctioning the bile or collecting the stones in a retrieval bag followed by thorough peritoneal irrigation and suctioning. However, care should be taken to avoid spreading of stones to difficult sites so that conversion to open for stones retrieval is unnecessary. ${ }^{18}$

This study has certain limitations. This is a single centre study with relatively small sample size so the findings cannot be generalized. This study was designed to see only prevalence of SSI in patients with BS during LC and confounding factors associated with SSI has not been taken into consideration.

\section{Conclusion}

The present study reveals that iatrogenic gallbladder perforation with BS has higher prevalence of port site SSI.

\section{Acknowledgement:}

The author would like to thank all the patients, faculty members and residents of surgery department without whom this study would not have been possible. 


\section{References}

1. Dubois F, Icard P, Berthelot G, Levard H. Coelioscopic cholecystectomy. Preliminary report of 36 cases. Ann Surg. 1990;211(1):60-2.

2. Soper NJ, Stockmann PT, Dunnegan DL, Ashley SW. Laparoscopic cholecystectomy. The new 'gold standard'? Arch Surg. 1992;127(8):917-21.

3. Soper NJ, Brunt LM, Kerbl K. Laparoscopic general surgery. N Engl J Med. 1994;330(6):409-19.

4. McMahon AJ, Russell IT, Baxter JN, Ross S, Anderson JR, Morran CG, et al. Laparoscopic versus minilaparotomy cholecystectomy: a randomised trial. Lancet. 1994;343(8890):135-8.

5. Barkun JS, Barkun AN, Sampalis JS, Fried G, Taylor B, Wexler MJ, et al. Randomised controlled trial of laparoscopic versus mini cholecystectomy. The McGill Gallstone Treatment Group. Lancet. 1992;340(8828):1116-9.

6. Peters JH, Gibbons GD, Innes JT, Nichols KE, Front ME, Roby SR, et al. Complications of laparoscopic cholecystectomy. Surgery. 1991;110(4):769-77.

7. Soper NJ, Dunnegan DL. Does intraoperative gallbladder perforation influence the early outcome of laparoscopic cholecystectomy? Surg Laparosc Endosc. 1991;1(3):156-61.

8. Kimura T, Goto H, Takeuchi Y, Yoshida M, Kobayashi T, Sakuramachi S, et al. Intraabdominal contamination after gallbladder perforation during laparoscopic cholecystectomy and its complications. Surg Endosc. 1996;10(9):888-91.

9. Suh SW, Park JM, Lee SE, Choi YS. Accidental gallbladder perforation during laparoscopic cholecystectomy: does it have an effect on the clinical outcomes? J Laparoendosc Adv Surg Tech A. $2012 ; 22(1): 40-5$.

10. Rice DC, Memon MA, Jamison RL, Agnessi $\mathrm{T}$, Ilstrup $\mathrm{D}$, Bannon $\mathrm{MB}$, et al. Long-term consequences of intraoperative spillage of bile and gallstones during laparoscopic cholecystectomy. J Gastrointest Surg. 1997;1(1):85-90.
11. Gibson A, Tevis S, Kennedy G. Readmission after delayed diagnosis of surgical site infection: a focus on prevention using the American College of Surgeons National Surgical Quality Improvement Program. Am J Surg. 2014;207(6):832-9.

12. Down SK, Nicolic M, Abdulkarim H, Skelton N, Harris AH, Koak Y. Low ninety-day re-admission rates after emergency and elective laparoscopic cholecystectomy in a district general hospital. Ann R Coll Surg Engl. 2010;92(4):307-10.

13. Berríos-Torres SI, Umscheid CA, Bratzler DW, Leas B, Stone EC, Kelz RR, et al. Centers for Disease Control and Prevention Guideline for the Prevention of Surgical Site Infection, 2017. JAMA Surgery. 2017;152(8):784-91.

14. Sarli L, Pietra N, Costi R, Grattarola M. Gallbladder perforation during laparoscopic cholecystectomy. World J Surg. 1999;23(11):1186-90.

15. Rice DC, Memon MA, Jamison RL, Agnessi T, Ilstrup $\mathrm{D}$, Bannon MB, et al. Long-term consequences of intraoperative spillage of bile and gallstones during laparoscopic cholecystectomy. J Gastrointest Surg. (10):1997 Jan-Feb;1(1):85-90; discussion 90-1.

16. Peponis T, Eskesen TG, Mesar T, Saillant N, Kaafarani HMA, Yeh DD, et al. Bile Spillage as a Risk Factor for Surgical Site Infection after Laparoscopic Cholecystectomy: A Prospective Study of 1,001 Patients. J Am Coll Surg. 2018;226(6):1030-5.

17. Giger UF, Michel JM, Opitz I, Th Inderbitzin D, Kocher T, Krähenbühl L. Risk factors for perioperative complications in patients undergoing laparoscopic cholecystectomy: analysis of 22,953 consecutive cases from the Swiss Association of Laparoscopic and Thoracoscopic Surgery database. J Am Coll Surg. 2006;203(5):723-8.

18. Klaiber C, Metzger A, Saager C. The "shuttle" stone collector - a new device for collecting lost gallstones in laparoscopic cholecystectomy. Surgical Endoscopy. 1992;6(2):84. 